\title{
PENGARUH MODEL PEMBELAJARAN BERBASIS MASALAH TERHADAP KEMAMPUAN BERPIKIR ALJABAR SISWA DALAM MEMECAHKAN MASALAH MATEMATIKA PADA SISWA KELAS VII MTs NEGERI 2 KENDARI
}

\author{
Susi La Resi ${ }^{1)}$, Hafiludin Samparadja ${ }^{2}$, Jafar Masuha ${ }^{3)}$ \\ ${ }^{1)}$ Alumni Jurusan Pendidikan Matematika, ${ }^{2,3)}$ Dosen Jurusan Pendidikan Matematika \\ FKIP Universitas Halu Oleo Email: laresisusi96@gmail.com
}

\begin{abstract}
Abstrak
Penelitian ini bertujuan untuk mengetahui: 1) gambaran kemampuan berpikir aljabar siswa yang diajarkan dengan model pembelajaran berbasis masalah (PBM); 2) gambaran kemampuan berpikir aljabar siswa yang diajarkan dengan pendekatan pembelajaran konvensional; dan 3) perbedaan kemampuan berpikir aljabar antara siswa yang diajar dengan model PBM dan siswa yang diajar dengan pendekatan pembelajaran konvensional. Populasi penelitian ini adalah seluruh siswa kelas VII MTs Negeri 2 Kendari dengan teknik pengambilan sampel secara purposive sampling. Hasil penelitian ini adalah: 1) kemampuan berpikir aljabar siswa yang diajarkan dengan model PBM diperoleh rata-rata 67.5 , median 67.5 , modus 70 , dan varians $150 ; 2$ ) kemampuan berpikir aljabar siswa yang diajarkan dengan pendekatan pembelajaran konvensional diperoleh rata-rata 57.188, median 55, modus 65, dan varians 83.77; dan (3) kemampuan berpikir aljabar siswa setelah diajar dengan model PBM lebih baik secara signifikan daripada rerata kemampuan berpikir aljabar siswa setelah diajar dengan pendekatan pembelajaran konvensional pada materi aljabar.
\end{abstract}

Kata Kunci: kemampuan berpikir, pembelajaran berbasis masalah, dan pendekatan konvensional.

\section{THE EFFECT OF PROBLEM BASED LEARNING MODEL ON THE STUDENTS ALGEBRAIC THINKING ABILITY IN SOLVING MATHEMATICS PROBLEM AT THE VII GRADERS OF MTS NEGERI 2 KENDARI}

\begin{abstract}
This study aims to determine: 1) description of the results of the algebraic thinking ability of students taught by a model of Problem Based Learning (PBL); 2) description of the algebraic thinking ability of students taught by convensional approach; and 3) the significant difference between the algebraic thinking ability students who have been taught by using PBL model and conventional approach. The population of this study was all of students at graders VII of MTs Negeri 2 Kendari by using a sampling technique is purposive sampling. The result of this study were: 1) the algebraic thinking ability of students who have been taught by using a model of PBL value is the mean is 67.5 ; median 67.5; mode70; and variance $150 ; 2$ ) the algebraic thinking ability of students who have been taught by using conventional approach value is the mean 57.188; median 55; mode 65; and variance 83.77; and (3) the algebraic thinking ability of students who have been taught by using a model of PBL is significantly better than the algebraic thinking ability of students who have been taught by using convensional approach in material algebra.
\end{abstract}

Keywords: thinking ability, convensional approach, and problem based learning. 


\section{Pendahuluan}

Berpikir merupakan suatu kegiatan mental yang melibatkan kerja otak. Dengan berpikir, maka manusia dapat dengan lebih mudah mengatasi kesulitan dan masalah hidup. Dalam proses mengatasi masalah kita dapat berpikir dengan cara yang berbeda-beda, karena memang pada dasarnya ada beberapa cara berpikir, meski tidak semuanya efektif untuk memecahkan suatu masalah. Siswono (2007: 34) mengatakan bahwa berpikir juga merupakan suatu kegiatan mental yang dialami seseorang bila mereka dihadapkan pada suatu masalah atau situasi yang harus dipecahkan. Pendapat ini menegaskan bahwa ketika seseorang merumuskan suatu masalah, memecahkan masalah, ataupun ingin memahami sesuatu, maka ia melakukan suatu aktivitas berpikir. Berpikir terdiri dari beberapa jenis, salah satunya berpikir Aljabar.

Berpikir aljabar adalah kemampuan untuk memahami pola, hubungan dan fungsi, menganalisis situasi matematika dan struktur menggunakan simbol-simbol aljabar, dan model matematika untuk mewakili dan memahami hubungan kuantitatif, dan menganalisis perubahan dalam berbagai konteks (Hayati, 2013: 400). Berpikir aljabar merupakan elemen penting dan mendasar dari berpikir matematika. Berpikir aljabar merupakan berpikir matematika yang berkaitan dengan salah satu aspek matematika, dan kajian dasar aljabar diawali dengan penyajian simbolik kuantitas serta operasi-operasinya, meliputi persamaan, persamaan linear, dan persamaan kuadrat. Aljabar juga sering dimaknai sebagai bahasa simbol dan relasi (Warsitasari, 2015: 2).

Namun, aljabar yang harusnya penting justru memberikan masalah tersendiri bagi siswa. Siswa umumnya mengalami kesulitan dalam mempelajarinya. Wardhani (2004: 1) mengungkapkan kesulitan yang dihadapi siswa SMP (Sekolah Menengah Pertama) pada lima provinsi yang diselenggarakan PPPG (Pusat Pengembangan Penataan Guru) matematika tahun 2002 tentang aljabar. Kajian ini menunjukan hampir semua provinsi menghadapi masalah rendahnya pemahaman siswa pada konsep operasi aljabar dan keterampilan yang rendah dalam menyelesaikan operasi bentuk aljabar.

MTsN 2 Kendari merupakan sekolah yang menghadapi masalah rendahnya pemahaman siswa pada konsep operasi aljabar dan keterampilan yang rendah dalam menyelesaikan operasi bentuk aljabar. Dari hasil observasi yang dilakukan peneliti pada sekolah tersebut ditemukan bahwa penyampain materi yang dilakukan oleh guru menggunakan strategi ekspositori yaitu menyampaikan materi langsung kepada siswa dan menggunakan media papan tulis sebagai sarana pembelajarannya. Hasil wawancara dengan guru matematika di sekolah tersebut menyebutkan bahwa siswa pada kelas observasi menganggap aljabar adalah materi yang sulit dikuasai terutama yang berkaitan dengan operasi aljabar.

Salah satu faktor penyebab rendahnya kemampuan berpikir aljabar siswa adalah penggunaan model pembelajaran yang kurang tepat. Salah satu model pembelajaran yang dapat digunakan untuk meningkatkan kemampuan berpikir aljabar siswa adalah model pembelajaran berbasis masalah (PBM). Menurut Arends (Fachrurazi, 2011: 80) pembelajaran berbasis masalah (PBM) merupakan suatu pendekatan pembelajaran dimana siswa mengerjakan permasalahan yang autentik dengan maksud untuk menyusun pengetahuan mereka sendiri, mengembangkan inkuiri dan keterampilan berpikir, mengembangkan kemandirian, dan percaya diri.

Rusman (2010: 229) mengatakan bahwa model pembelajaran berbasis masalah (MPBM) merupakan salah satu alternatif model pembelajaran yang dapat mengembangkan keterampilan berpikir siswa (penalaran, komunikasi dan koneksi) dalam memecahkan masalah. Sebagai salah satu keterampilan berpikir, berpikir aljabar sangat terkait dengan kemampuan memecahkan masalah. Model pembelajaran berbasis masalah merupakan model yang dapat meningkatkan kemampuan memecahkan masalah matematika. Sehingga dengan model pembelajaran berbasis masalah diharapkan dapat meningkatkan kemampuan berpikir aljabar siswa dalam memecahkan masalah matematika.

Uraian di atas mendorong peneliti untuk melakukan penelitian tentang kemampuan berpikir aljabar siswa dengan menggunakan soal-soal berbasis pemecahan masalah. Pada penelitian ini diterapkan model pembelajaran berbasis masalah (PBM) pada kelas eksperimen.

Langrall (Patton dan Santos, 2012: 7) mendefinisikan bahwa dalam berpikir aljabar melibatkan operasi pada bilangan yang tidak 
pasti atau bilangan yang sudah dilambangkan dengan variabel, sedangkan aritmatika melibatkan perhitungan pada bilangan yang pasti. Sedangkan Warsitasari (2015: 4) mengungkapkan bahwa berpikir aljabar terjadi dengan diawali kepekaan seseorang tentang sesuatu atau objek yang tidak dapat ditentukan secara pasti ("sesuatu yang tidak diketahui", variabel, dan parameter), kemudian dilanjutkan dengan dilakukannya analisis terhadap objek tersebut dan yang terakhir adalah memodelkan objek yang sudah dianalisis dalam simbol.

Berdasarkan pendapat para ahli di atas dapat disimpulkan bahwa berpikir aljabar merupakan berpikir matematika yang melibatkan operasi terhadap objek yang belum diketahui nilainya yang berupa variabel atau simbol kemudian dilakukan analisis terhadap objek tersebut. Sedangkan kemampuan berpikir aljabar adalah kesanggupan atau kecakapan seorang individu dalam menguasai suatu keahlian yang melibatkan operasi terhadap objek yang belum diketahui nilainya yang berupa variabel atau simbol kemudian dilakukan analisis terhadap objek tersebut dan digunakan untuk menyelesaikan suatu permasalahan matematika.

Warsitasari (2015: 4) merumuskan indikator berpikir aljabar berdasarkan pendapat Lew (2004) tentang jenis berpikir yang dilibatkan dalam berpikir aljabar. Siswa dikatakan berpikir aljabar jika dalam proses pemecahan masalah menunjukkan minimal salah satu indikator dari berpikir aljabar (algebraic thinking): (1) melakukan generalisasi, yaitu menyatakan pola atau memformulasikan keumuman secara simbolis, (2) melakukan abstraksi, yaitu mengekstraksi objek dan hubungan matematika berdasarkan generalisasi, (3) berpikir analitis, yaitu menyelesaikan persamaan untuk menentukan nilai yang tidak diketahui (unknown quantity), (4) berpikir dinamis, yaitu melakukan manipulasi dinamis dari objek matematika, dan (5) pemodelan, yaitu merepresentasikan masalah dalam model matematika.

Tabel 1

Indikator Berpikir Aljabar dalam Kegiatan Pemecahan Masalah

\begin{tabular}{|c|c|c|}
\hline $\begin{array}{c}\text { Kegiatan } \\
\text { Pemecahan Masalah }\end{array}$ & Indikator Berpikir Aljabar & Contoh Deskriptor \\
\hline \multirow[t]{2}{*}{$\begin{array}{l}\text { Mengekstrak infor- } \\
\text { masi dari situasi }\end{array}$} & \multirow{2}{*}{$\begin{array}{l}\text { Menyatakan pola atau } \\
\text { memformulasikan ke- } \\
\text { umuman secara simbolis. }\end{array}$} & $\begin{array}{l}\text { Memahami yang ditanyakan pada soal yang } \\
\text { melibatkan penggunaan simbol berupa huruf. }\end{array}$ \\
\hline & & $\begin{array}{l}\text { Menggunakan simbol dalam membuat model } \\
\text { matematika untuk menyelesaikan masalah } \\
\text { dengan tepat. }\end{array}$ \\
\hline \multirow{2}{*}{$\begin{array}{l}\text { Menyajikan kembali } \\
\text { informasi secara } \\
\text { matematis }\end{array}$} & \multirow{2}{*}{$\begin{array}{l}\text { Merepresentasikan } \\
\text { masalah dalam model } \\
\text { matematika. }\end{array}$} & $\begin{array}{l}\text { Membuat gambar untuk merepresentasikan } \\
\text { kembali informasi pada soal. }\end{array}$ \\
\hline & & $\begin{array}{l}\text { Menuliskan persamaan atau model } \\
\text { matematika yang menggambarkan masalah } \\
\text { yang akan dipecahkan. }\end{array}$ \\
\hline \multirow[t]{3}{*}{$\begin{array}{l}\text { Menafsirkan dan } \\
\text { menerapkan temuan } \\
\text { matematika }\end{array}$} & \multirow[t]{2}{*}{$\begin{array}{lr}\text { Melakukan } & \text { manipulasi } \\
\text { dinamis dari } & \text { objek } \\
\text { matematika. } & \end{array}$} & $\begin{array}{l}\text { Melakukan manipulasi aljabar untuk } \\
\text { menyederhana-kan persamaan atau model } \\
\text { matematika. }\end{array}$ \\
\hline & & $\begin{array}{l}\text { Menuliskan bentuk aljabar ke dalam bentuk } \\
\text { yang lebih sederhana. }\end{array}$ \\
\hline & $\begin{array}{l}\text { Menyelesaikan persamaan } \\
\text { untuk menentukan nilai } \\
\text { yang tidak diketahui atau } \\
\text { menentukan nilai suatu } \\
\text { variabel. }\end{array}$ & Menyelesaikan persamaan. \\
\hline
\end{tabular}

Indikator berpikir aljabar yang dimaksud dalam penelitian ini yaitu merujuk pada indikator yang dikemukakan oleh Warsitasari (2015: 4) dengan memfokuskan pada indikator melakukan gemeralisasi, berpikir analitis, berpikir dinamis, dan pemodelan. Sehingga siswa diharapkan mampu: (1) menyatakan pola atau memformulasikan 


\section{Jurnal Penelitian Pendididikan Matematika Volume 7 No.2 Mei 2019}

keumuman secara simbolis, (2) merepresentasikan masalah dalam model matematika, dan (3) melakukan manipulasi dinamis dari objek matematika, dan (4) menyelesaikan persamaan untuk menentukan nilai yang tidak diketahui atau menentukan nilai suatu variabel. Sedangkan indikator berpikir aljabar dalam pemecahan masalah dalam penelitian ini dapat dilihat pada Tabel 1 .

Pembelajaran berbasis masalah adalah suatu model pembelajaran yang menggunakan masalah kontekstual sebagai suatu konteks bagi siswa untuk belajar tentang cara berpikir kritis dan ketrampilan pemecahan masalah, serta untuk memperoleh pengetahuan dan konsep yang esensial dari materi pelajaran (Sudarman, 2007: 68). Menurut Arends (Fachrurazi, 2011: 80) pembelajaran berbasis masalah (PBM) merupakan suatu pendekatan pembelajaran di mana siswa mengerjakan permasalahan yang autentik dengan maksud untuk menyusun pengetahuan mereka sendiri, mengembangkan inkuiri dan keterampilan berpikir, mengembangkan kemandirian, dan percaya diri.

Berdasarkan pendapat para ahli di atas, dapat disimpulkan bahwa pembelajaran berbasis masalah merupakan suatu model pembelajaran yang diawali dengan penyajian masalah yang relevan dengan pengalaman siswa dalam dunia nyata dan dikaitkan dengan ide-ide atau topiktopik dalam matematika sehingga siswa dapat memahami konsep dengan baik, dapat meningkatkan kemampuan berpikir aljabar, memiliki kemandirian belajar, keterampilan berpartisipasi dalam kerja kelompok, dan kemampuan pemecahan masalah.

Menurut Hung (Sari dkk, 2014, 56), peserta didik memperoleh beberapa manfaat melalui PBM yaitu: (1) dapat beradaptasi dengan perubahan, (2) dapat bernalar dan berhadapan dengan masalah, (3) membiasakan bersikap empati, bekerja sama dan menghargai orang lain, (4) mengidentifikasi kelemahan dan kekuatan sendiri, (5) memelihara suatu pembelajaran dengan terbuka, kritis dan aktif. Hal tersebut menjelaskan bahwa PBM dapat memberikan manfaat dalam kehidupan peserta didik. Melalui pendekatan PBM, peserta didik dapat belajar memecahkan masalah, menggunakan penalaran dan bekerjasama dengan orang lain.

Ibrahim dan Nur (2000: 13) dan Ismail (2002: 1) dalam Rusman (2010: 243) mengemukakan bahwa langkah-langkah Pembelajaran Berbasis Masalah ditampilkan dalam Tabel 2 berikut.

Tabel 2

Langkah-Langkah Pembelajaran Berbasis Masalah

\begin{tabular}{|c|c|c|}
\hline No & Fase & Tingkah Laku Guru \\
\hline 1 & Orientasi Siswa Pada Masalah & $\begin{array}{l}\text { Menjelaskan Tujuan Pembelajaran, dan memotivasi } \\
\text { siswa terlibat pada aktivitas pemecahan masalah }\end{array}$ \\
\hline 2 & $\begin{array}{l}\text { Mengorganisasi siswa untuk } \\
\text { belajar }\end{array}$ & $\begin{array}{l}\text { Membantu siswa mendefinisikan dan } \\
\text { mengorganisasikan tugas belajar yang berhubungan } \\
\text { dengan masalah tersebut }\end{array}$ \\
\hline 3 & $\begin{array}{l}\text { Membimbing pengalaman } \\
\text { individu/ kelompok }\end{array}$ & $\begin{array}{l}\text { Mendorong siswa untuk mengumpulkan informasi } \\
\text { yang sesuai, melaksanakan eksperimen untuk } \\
\text { mendapatkan penjelasan dan pemecahan masalah }\end{array}$ \\
\hline 4 & $\begin{array}{l}\text { Mengembangkan } \\
\text { menyajikan hasil karya }\end{array}$ & $\begin{array}{l}\text { Membantu siswa dalam merencanakan dan } \\
\text { menyiapkan karya yang sesuai seperti laporan, } \\
\text { model dan membantu mereka untuk berbagai tugas } \\
\text { dengan temannya }\end{array}$ \\
\hline 5 & $\begin{array}{l}\text { Menganalisa dan mengevaluasi } \\
\text { proses pemecahan masalah }\end{array}$ & $\begin{array}{l}\text { Mengevaluasi hasil belajar tentang materi yang } \\
\text { telah dipelajari/ meminta kelompok } \\
\text { mempresentasikan hasil kerja tentang materi yang } \\
\text { telah dipelajari }\end{array}$ \\
\hline
\end{tabular}

Pembelajaran melalui pembelajaran berbasis masalah merupakan suatu rangkaian kegiatan belajar yang diharapkan dapat memberdayakan siswa untuk menjadi seorang individu yang mandiri dan mampu menghadapi setiap permasalahan dalam hidupnya di 
kemudian hari. Selain itu pengajaran berdasarkan masalah juga diharapkan dapat membantu siswa untuk memproses informasi yang sudah jadi dalam benaknya dan menyusun pengetahuan mereka sendiri tentang dunia sosial dan sekitarnya.

Melalui pendekatan PBM, diharapkan siswa dapat berlatih mengaitkan masalah kehidupan sehari-hari dengan pembelajaran matematika, sehingga matematika tidak lagi terlalu abstrak bagi mereka dan pembelajaran menjadi lebih bermakna. Fogarty (Sari dkk, 2014, 56) mendefinisikan PBM sebagai suatu model kurikulum yang didisain di seputar masalah dunia nyata yang tidak terstruktur, open-ended atau ambigu. Suatu masalah yang tidak terstruktur bersifat samar-samar, tidak jelas, atau belum teridentifikasi. Situasi yang diciptakan dalam permasalahan tersebut seringkali membingungkan dan kompleks, serta memuat hal-hal yang tidak berhubungan.

\section{Metode}

Penelitian ini dilaksanakan di MTs Negeri 2 Kendari pada siswa kelas VII. Waktu pelaksanaan penelitian ini pada semester ganjil tahun ajaran 2015/2016. Tahapan pelaksanaan penelitian ini dilaksanakan pada bulan JuliOktober 2015. Desain dalam penelitian ini dapat dilihat pada Tabel 3 berikut.

Tabel 3

Desain Penelitian

\begin{tabular}{|c|c|c|}
\hline $\mathrm{R}$ & $\mathrm{X}$ & $\mathrm{O}_{1}$ \\
\hline $\mathrm{R}$ & - & $\mathrm{O}_{2}$ \\
\hline
\end{tabular}

(Sugiyono, 2013: 76)

Keterangan :

$\mathrm{R}$ = dua kelompok yang dipilih secara random

$\mathrm{X}=$ perlakuan dengan penerapan model pembelajaran PBM pada kelas eksperimen.

$\mathrm{O}_{1}=$ tes kemampuan berpikir aljabar siswa setelah perlakuan pada kelas eksperimen.

$\mathrm{O}_{2}=$ tes kemampuan berpikir aljabar siswa setelah perlakuan pada kelas kontrol.

Populasi dalam penelitian ini adalah seluruh siswa kelas VII MTs Negeri 2 Kendari, pada tahun pelajaran 2018/2019 yang tersebar dalam 6 kelas paralel. Penyebaran siswa pada kelas VII MTs Negeri 2 Kendari ini dilakukan secara merata sehingga mempunyai peluang yang sama untuk diambil sebagai sampel penelitian.

Berdasarkan nilai rata-rata ulangan harian matematika siswa kelas VII tahun pelajaran 2018/2019 terdapat dua kelas yang mempunyai nilai rata- rata relatif sama dan mempunyai varians yang homogen (uji homogenitas varians) yaitu kelas $\mathrm{VII}_{2}$ dan $\mathrm{VII}_{3}$ sehingga kedua kelas tersebut dijadikan sampel penelitian. Jadi, teknik yang digunakan adalah Purposive Sampling dengan pertimbangan kedua kelas mempunyai kemampuan awal yang relatif sama. Sedangkan untuk menentukan kelas yang menggunakan model pembelajaran berbasis masalah dan kelas yang menggunakan pendekatan konvensional dilakukan dengan cara random kelas. Berdasarkan teknik tersebut diperoleh kelas $\mathrm{VII}_{2}$ sebagai kelas yang menggunakan model pembelajaran berbasis masalah dan kelas $\mathrm{VII}_{3}$ sebagai kelas yang menggunakan pendekatan konvensional.

Instrumen atau alat ukur yang digunakan dalam penelitian ini ada dua macam, yaitu:

1. Lembar Pengamatan

Pengukuran keberlangsungan (terlaksana/tidaknya) model pembelajaran berbasis masalah dan pendekatan konvensional di dalam penelitian ini menggunakan lembar pengamatan/ observasi pada setiap kegiatan tatap muka (proses pembelajaran). Lembar pengamatan ini diisi oleh para observer.

2. Instrumen Kemampuan Berpikir Aljabar Siswa

Tes yang digunakan berupa tes tertulis sebanyak 5 nomor dalam bentuk essay pokok bahasan aljabar yang digunakan untuk mengukur kemampuan berpikir aljabar siswa setelah pembelajaran, baik pada kelas yang menggunakan model pembelajaran berbasis masalah maupun kelas yang menggunakan pendekatan konvensional. Sebelum digunakan sebagai instrumen, tes tersebut terlebih dahulu dilakukan uji panelis dan kemudian diuji 


\section{Jurnal Penelitian Pendididikan Matematika Volume 7 No.2 Mei 2019}

cobakan untuk mengetahui validitas dan reliabilitasnya.

Uji validitas adalah suatu ukuran yang menunjukkan keshahihan atau tingkat kevalidan suatu instrumen. Untuk tes uraian, validitas butir tesnya dihitung dengan menggunakan rumus korelasi product moment dengan angka kasar sebagai berikut:
Dimana :

$\mathrm{x} \quad=$ Skor item

$\mathrm{n} \quad=$ Jumlah subyek

$\mathrm{y}=$ Skor total

$\mathrm{r}_{\mathrm{xy}}=$ Koefisien korelasi antara variabel $\mathrm{X}$ dan Y

Dengan kriteria pengujian pada taraf signifikan $\alpha=0,05$ :

$\mathrm{r}_{\mathrm{xy}} \geq \mathrm{r}_{\text {tabel }}$ (valid)

$r_{x y}<r_{\text {tabel }}$ (tidak valid)

Untuk mengetahui reliabilitas tes uraian digunakan rumus Alpha Cronbach sebagai berikut:

$r_{i}=\frac{k}{k-1}\left\{1-\frac{\sum S_{i}^{2}}{S_{t}^{2}}\right\}$

(Sugiyono, 2013: 365)

Keterangan:

$\mathrm{r}_{\mathrm{i}}=$ Koefisien reliabilitas (reliabel $\geq 0,6$ )

$\mathrm{s}_{\mathrm{i}}^{2}=$ Varians skor butir ke-i

$\mathrm{k}=$ Banyak butir

$\mathrm{s}_{\mathrm{t}}^{2}=$ Varians skor total.

Untuk menentukan tinggi rendahnya reliabilitas sebuat tes menggunakan ketentuan sebagai berikut:

$r_{\mathrm{i}} \leq 0.20 \quad$ Tingkat reliabilitas tes sangat rendah,

$0.20<r_{\mathrm{i}} \leq 0.40$ Tingkat reliabilitas tes rendah,

$0.40<r_{i} \leq 0.60$ Tingkat reliabilitas tes sedang,

$0.60<r_{\mathrm{i}} \leq 0.80$ Tingkat reliabilitas tes tinggi,

$0.80<r_{\mathrm{i}} \leq 1.00$ Tingkat reliabilitas tes sangat tinggi.

Pengumpulan data dalam penelitian ini dilakukan dengan pemberian berupa lembar observasi dan tes hasil belajar matematika siswa dalam bentuk essay kepada siswa. Observasi dilakukan pada saat proses pembelajaran berlangsung di kelas, baik dikelas yang menggunakan model pembelajaran berbasis masalah maupun kelas yang menggunakan pendekatan konvensional pada setiap pertemuan yaitu lima kali pertemuan. Hasilnya dipergunakan untuk memperoleh data tentang aktivitas/partisipasi guru dan siswa. Setelah kegiatan pembelajaran, maka diadakan tes kemampuan berpikir aljabar pada kedua kelas
(Sugiyono, 2013: 356)

${ }^{2}\left\{\left\{n \sum y_{i}{ }^{2}-\left(\sum y_{i}\right)^{2}\right\}\right.$

untuk mengetahui kemampuan berpikir aljabar siswa kedua kelas tersebut.

Perolehan data dalam penelitian ini dilaksanakan dengan tes kemampuan berpikir aljabar siswa. Tes diberikan setelah kedua kelas diberikan pembelajaran dengan model yang berbeda, kelas eksperimen diajar menggunakan model pembelajaran berbasis masalah, sedangkan kelas kontrol diajar menggunakan pendekatan konvensional. Soal-soal yang diberikan pada kedua kelas adalah sama. Kemudian tes tersebut dikerjakan oleh siswa, selanjutnya hasil pekerjaan siswa dikumpulkan oleh peneliti untuk diperiksa dan diberi nilai. Nilai dari hasil pekerjaan siswa inilah yang dijadikan sebagai data dalam penelitian ini.

Analisis data dalam penelitian ini menggunakan analisis deskriptif dan analisis inferensial. Analisis deskriptif digunakan untuk mendeskriptifkan karakteristik data masingmasing kelompok. Analisis statistik deskriptif menggunakan ukuran rata-rata, median, modus, simpangan baku, varians, minimum, dan maksimum.

Analisis inferensial digunakan untuk menguji hipotesis dengan statistik uji-t. Sebelum diadakan uji- $t$ diperiksa terlebih dahulu kenormalan data dan homogenitas data. Uji normalitas data dimaksudkan untuk mengetahui apakah data yang diteliti berasal dari populasi yang berdistribusi normal atau tidak. Asumsi kenormalan data kemampuan berpikir aljabar pada kelas eksperimen dan kelas kontrol menggunakan uji Kolmogorov-Smirnov. Sedangkan uji homogenitas varian dilakukan untuk menentukan apakah data pada kelas eksperimen dan kelas kontrol mempunyai varian yang homogen atau tidak. Uji yang digunakan adalah uji F.

\section{Hasil}

1. Hasil Analisis Deskriptif

a. Hasil Observasi Pelaksanaan Pembelajaran Model Pembelajaran Berbasis Masalah (PBM) oleh Guru 
Hasil observasi pelaksanaan masalah (PBM) dapat terlihat dalam Tabel 4 pembelajaran yang dilakukan guru berikut. menggunakan model pembelajaran berbasis

Tabel 4

Rekapitulasi Pengelolaan Pembelajaran oleh Guru pada Pembelajaran Berbasis Masalah (PBM)

\begin{tabular}{|c|c|c|}
\hline Pertemuan & Skor Total & Persentase (\%) \\
\hline I & 56 & $77,78 \%$ \\
\hline II & 63 & $87,50 \%$ \\
\hline III & 68 & $94,44 \%$ \\
\hline IV & 70 & $97,22 \%$ \\
\hline V & 72 & $100 \%$ \\
\hline
\end{tabular}

Berdasarkan Tabel 4 dapat dilihat bahwa keberhasilan pengelolaan pembelajaran pada pertemuan pertama dapat dikatakan baik dengan tingkat keberhasilan $77,78 \%$. Pelaksanaan pembelajaran pada pertemuan kedua mengalami peningkatan yang baik dibanding pada pertemuan pertama dengan $\mathrm{t}$ ingkat keberhasilan mencapai 87,50\%. Pengelolaan pembelajaran pada pertemuan ketiga dengan tingkat keberhasilan mencapai 94,44\%. Pengelolaan pembelajaran pada pertemuan keempat mengalami peningkatan dibanding pada pertemuan sebelumnya, dengan tingkat keberhasilan mencapai $97,22 \%$ dan pengelolaan pembelajaran pada pertemuan kelima mencapai $100 \%$ yang dimana guru melaksanakan seluruh kegiatan pembelajaran dengan baik. Dalam hal ini guru telah melaksanakan seluruh rangkaian kegiatan pembelajaran model pembelajaran berbasis masalah (PBM) dan guru sudah mampu mengorganisasikan waktu secara optimal.

b. Hasil Observasi Aktivitas Siswa dalam Pelaksanaan Pembelajaran menggunakan Model Pembelajaran Berbasis Masalah (PBM).

Hasil observasi aktivitas siswa dalam pelaksanaan model Pembelajaran Berbasis Masalah (PBM) dapat terlihat dalam Tabel 5 berikut.

Tabel 5

Rekapitulasi Keaktifan Siswa Pada Pembelajaran

Model Pembelajaran Berbasis Masalah (PBM)

\begin{tabular}{|c|c|c|}
\hline Pertemuan & Skor Total & Persentase (\%) \\
\hline I & 41 & $85,42 \%$ \\
\hline II & 44 & $91,67 \%$ \\
\hline III & 45 & $93,75 \%$ \\
\hline IV & 47 & $97,92 \%$ \\
\hline V & 48 & $100 \%$ \\
\hline Skor Max & 48 & \\
\hline
\end{tabular}

Berdasarkan Tabel 5 dapat dilihat bahwa pada pertemuan pertama ketercapaian seluruh aspek yang diamati mencapai $85,42 \%$. Pertemuan kedua sampai dengan pertemuan kelima, memperlihatkan ketercapaian aspek yang diamati berturut-turut adalah 91,67\%; 93,75\%; 97,92\%; dan 100\%. Pada tiap pertemuan, ketercapaian aspek yang diamati selalu mengalami peningkatan. Dalam hal ini keaktifan siswa mengalami peningkatan pada setiap pertemuan.

c. Hasil Observasi Pelaksanaan Pembelajaran Pendekatan Konvensional oleh Guru

Hasil observasi pelaksanaan pembelajaran yang dilakukan guru menggunakan pendekatan konvensional dapat terlihat dalam Tabel 6. 
Tabel 6

Rekapitulasi Pengelolaan Pembelajaran oleh Guru pada Pendekatan Konvensional

\begin{tabular}{|c|c|c|}
\hline Pertemuan & Skor Total & Persentase (\%) \\
\hline I & 45 & $80,36 \%$ \\
\hline II & 48 & $82,71 \%$ \\
\hline III & 51 & $91,07 \%$ \\
\hline IV & 53 & $94,64 \%$ \\
\hline V & 56 & $100 \%$ \\
\hline Skor Max & 56 & \\
\hline
\end{tabular}

Berdasarkan Tabel 6 dapat dilihat bahwa keberhasilan pengelolaan pembelajaran pada pertemuan pertama tingkat keberhasilannya adalah $80,36 \%$. Pelaksanaan pembelajaran pada pertemuan kedua mengalami peningkatan dibanding pertemuan pertama. Tingkat keberhasilan mencapai $82,71 \%$. Pada pertemuan ketiga tingkat keberhasilah pengelolaan pembelajaran mengalami peningkatan dibandingkan dengan pertemuan kedua yaitu 91,07\%. Pada pertemuan keempat tingkat keberhasilah pengelolaan pembelajaran juga mengalami peningkatan dibandingkan dengan pertemuan ketiga yaitu 94,64\%. Dan pada pertemuan kelima pengelolaan pembelajaran mencapai $100 \%$. Secara keseluruhan, guru telah melaksanakan rangkaian kegiatan pembelajaran dengan menggunakan pendekatan konvensional dengan baik.

d. Hasil Observasi Aktivitas Siswa dalam Pelaksanaan Pembelajaran menggunakan Pendekatan Konvensional.

Hasil observasi aktivitas siswa dalam pelaksanaan pendekatan konvensional dapat terlihat dalam Tabel 7 berikut.

Tabel 7

Rekapitulasi Keaktifan Siswa pada Pendekatan

Konvensional

\begin{tabular}{|c|c|c|}
\hline Pertemuan & Skor Total & Persentase (\%) \\
\hline I & 33 & $75 \%$ \\
\hline II & 37 & $84,09 \%$ \\
\hline III & 40 & $90,91 \%$ \\
\hline IV & 42 & $95,45 \%$ \\
\hline V & 44 & $100 \%$ \\
\hline Skor Max & 44 & \\
\hline
\end{tabular}

Berdasarkan Tabel 7 dapat dilihat bahwa pada pertemuan pertama ketercapaian seluruh aspek yang diamati mencapai $75 \%$. Pertemuan kedua sampai dengan pertemuan kelima terus mengalami peningkatan dengan ketercapaian aspek yang diamati berturut-turut adalah $84,09 \%$; 90,91\%; 95,45\%, dan 97,92\%. Secara keseluruhan, siswa telah terbiasa mengikuti pembelajaran dengan menggunakan pendekatan konvensional dengan baik.

e. Hasil Analisis Deskriptif Kemampuan Berpikir Aljabar Siswa

Berdasarkan hasil analisis deskriptif kemampuan berpikir aljabar siswa dari data tes kemampuan berpikir aljabar yang diperoleh setelah di terapkan model pembelajaran berbasis masalah dengan jumlah siswa yang mengikuti tes sebanyak 32 orang dan pendekatan konvensional dengan jumlah siswa yang mengikuti tes sebanyak 32 orang, diperoleh data kemampuan berpikir aljabar siswa yang disajikan pada Tabel 8.

Berdasarkan hasil analisis deskriptif kemampuan berpikir aljabar pada Tabel 8 bahwa kemampuan berpikir aljabar siswa pada kelas yang diajar menggunakan model pembelajaran berbasis masalah (kelas eksperiman) diperoleh nilai rata-rata 67.5 dengan standar deviasi sebesar 12.247. Sedangkan untuk kelas yang diajar dengan pendekatan konvensional (kelas kontrol) diperoleh nilai rata-rata 57.188 dengan standar deviasi sebesar 9.153. 
Tabel 8

Deskriptif Kemampuan Berpikir Aljabar Siswa Kelas Eksperimen dan Kelas Kontrol

\begin{tabular}{|l|l|r|}
\hline \multicolumn{2}{|c|}{ Descriptives } \\
\hline \multirow{5}{*}{ Kelas Eksperimen } & 67.500 \\
& Mean & 67.500 \\
& Median & 70.000 \\
& Mode & 150.000 \\
& Variance & 12.247 \\
& Std. Deviation & 45.00 \\
& Minimum & 90.00 \\
\hline \multirow{5}{*}{ Kelas Kontrol } & Maximum & 57.188 \\
& Mean & 55.000 \\
& Median & 65.000 \\
& Mode & 83.770 \\
& Variance & 9.153 \\
& Std. Deviation & 40.00 \\
& Minimum & 75.00 \\
\hline
\end{tabular}

Nilai yang diperoleh pada kedua kelompok menunjukkan bahwa nilai tersebut mewakili kemampuan berpikir aljabar dari 32 siswa pada kelas pembelajaran berbasis masalah dan kemampuan berpikir aljabar dari 32 siswa pada kelas konvensional. Nilai median dan mode pada kelas pembelajaran berbasis masalah berturut-turut adalah 67.5 dan 70 serta variance adalah 150. Sedangkan nilai median dan mode pada kelas konvensional berturut-turut adalah 55 dan 65 serta variance adalah 83.77. Nilai minimum kelas pembelajaran berbasis masalah yaitu 45 dan nilai maksimummnya 90.
Sedangkan untuk kelas konvensional nilai minimumnya 40 dan nilai maksimumnya 75 .

2. Hasil Analisis Inferensial

a. Uji Normalitas

Uji normalitas digunakan untuk mengetahui apakah data kemampuan berpikir aljabar kedua kelas berdistribusi normal atau tidak. Untuk menguji apakah data berdistribusi normal atau tidak digunakan statistik uji normalitas dengan rumus Kolmogorov-Smirnov. Untuk lebih jelasnya hasil uji normalitas data hasil belajar matematika siswa pada kedua kelas tersebut dapat dilihat pada Tabel 9 berikut.

Tabel 9

Hasil Uji Normalitas Data Kemampuan Berpikir Aljabar Siswa Kelas Eksperimen dan Kelas Kontrol

\begin{tabular}{|ll|r|r|}
\hline \multicolumn{3}{|c|}{ One-Sample Kolmogorov-Smirnov Test } \\
\hline & & Kelas Kontrol & Kelas Eksperimen \\
\hline $\mathrm{N}$ & & 32 & 32 \\
Normal Parameters & & 57.1875 & 67.5000 \\
& Mean & 9.15260 & 12.24745 \\
Most Extreme & Std. Deviation & .147 & .138 \\
Differences & Absolute & .126 & .138 \\
Kolmogorov-Smirnov Z & Nositive & -.147 & -.111 \\
Asymp. Sig. (2-tailed) & & .832 & .780 \\
\hline
\end{tabular}

a. Test distribution is Normal.

b. Calculated from data. 


\section{Jurnal Penelitian Pendididikan Matematika Volume 7 No.2 Mei 2019}

Berdasarkan Tabel 9 di atas dapat dilihat bahwa nilai Asymp. Sig. (2-tailed) untuk kelas $\mathrm{VII}_{3}$ (kelas kontrol) adalah $0.493>\alpha$ (dengan $\alpha=0,05$ ), sehingga $\mathrm{H}_{0}$ diterima. Dengan demikian, dapat disimpulkan bahwa data kemampuan berpikir aljabar siswa kelas $\mathrm{VII}_{2}$ berdistribusi normal. Sedangkan untuk kelas $\mathrm{VII}_{2}$ (kelas eksperimen) terlihat bahwa nilai Asymp. Sig. (2-tailed) adalah $0.577>\alpha$ (dengan $\alpha=0,05$ ), sehingga $\mathrm{H}_{0}$ diterima.
Dengan demikian, dapat disimpulkan bahwa data kemampuan berpikir aljabar siswa kelas $\mathrm{VII}_{3}$ berdistribusi normal.

b. Uji Homogenitas

Uji homogenitas digunakan untuk mengetahui apakah data mempunyai varians yang sama (homogen) atau tidak. Hasil analisis Uji Homogenitas dapat dilihat pada Tabel 10 berikut

Tabel 10

Hasil Uji Homogenitas Data Kemampuan Berpikir

Aljabar Siswa Kelas Eksperimen dan Kelas Kontrol

\begin{tabular}{|c|c|c|c|}
\hline \multicolumn{4}{|c|}{ Test of Homogeneity of Variances } \\
\hline \multicolumn{4}{|c|}{ Kemampuan Berpikir Aljabar } \\
\hline Levene Statistic & df1 & $\mathrm{df} 2$ & Sig. \\
\hline 2.541 & 1 & 62 & .116 \\
\hline
\end{tabular}

Berdasarkan Tabel 10 di atas terlihat bahwa nilai signifikan statistik uji Test of Homogenity of Variances adalah 0,116. Nilai signifikan ini lebih besar dari taraf nyata signifikan 0,05 (nilai Sig. $=0,116>\alpha=0,05$ ) sehingga $\mathrm{H}_{0}$ diterima. Karena $\mathrm{H}_{0}$ diterima maka dapat disimpulkan bahwa varians kelompok data homogen. Hal ini menunjukkan bahwa data kemampuan berpikir aljabar siswa kelas $\mathrm{VII}_{2}$ dan siswa kelas $\mathrm{VII}_{3}$ memiliki varians yang homogen.

\section{c. Pengujian Hipotesis}

Uji perbedaan rata-rata kemampuan berpikir aljabar siswa dari siswa yang diajar menggunakan model pembelajaran berbasis masalah dan siswa yang diajar menggunakan pendekatan konvensional, apakah sesuai dengan nilai suatu perbedaan perbandingan atau nilai hipotesis, dalam hal ini untuk mengetahui apakah terdapat perbedaan yang signifikan rerata kemampuan berpikir aljabar siswa setelah diajar menggunakan model pembelajaran berbasis masalah dan siswa setelah diajar dengan menggunakan pendekatan konvensional.

Kriteria pengujian yang digunakan adalah jika nilai $t_{\text {hitung }} \leq \mathrm{t}_{\text {tabel }\left(1-\frac{\alpha}{2} ; n_{1}+n_{2}-2\right)}$ maka $\mathrm{H}_{0}$ diterima. Untuk lebih jelasnya hasil pengujian hipotesis data hasil belajar matematika siswa pada kelas yang diajar menggunakan model pembelajaran berbasis masalah dan kelas yang diajar menggunakan pendekatan konvensional dapat dilihat pada Tabel 11 berikut.

Tabel 11

Hasil Analisis Statistik Uji Hipotesis Kemampuan Berpikir Aljabar Siswa

Pada Kelas Eksperimen dan Kelas Kontrol

\begin{tabular}{|c|c|c|c|c|c|c|c|c|}
\hline \multicolumn{9}{|c|}{ Independent Samples Test } \\
\hline & & \multicolumn{7}{|c|}{ t-test for Equality of Means } \\
\hline & & \multirow[t]{2}{*}{$\mathrm{t}$} & \multirow[t]{2}{*}{$\mathrm{df}$} & \multirow[t]{2}{*}{$\begin{array}{l}\text { Sig. (2- } \\
\text { tailed) }\end{array}$} & \multirow[t]{2}{*}{$\begin{array}{c}\text { Mean } \\
\text { Difference }\end{array}$} & \multirow[t]{2}{*}{$\begin{array}{l}\text { Std. Error } \\
\text { Difference }\end{array}$} & \multicolumn{2}{|c|}{$\begin{array}{l}95 \% \text { Confidence } \\
\text { Interval of the } \\
\text { Difference }\end{array}$} \\
\hline & & & & & & & Lower & Upper \\
\hline \multirow{2}{*}{$\begin{array}{l}\text { Kemampuan } \\
\text { Berpikir } \\
\text { Aljabar }\end{array}$} & $\begin{array}{l}\text { Equal variances } \\
\text { assumed }\end{array}$ & 3.815 & 62 & .000 & 10.313 & 2.703 & 4.910 & 15.715 \\
\hline & $\begin{array}{l}\text { Equal variances } \\
\text { not assumed }\end{array}$ & 3.815 & 57.393 & .000 & 10.313 & 2.703 & 4.901 & 15.724 \\
\hline
\end{tabular}


Berdasarkan Tabel 11 di atas dapat dilihat bahwa nilai Sig. (2-tailed) adalah $0.000<\alpha$ (dengan $\alpha=0,05$ ), sehingga $\mathrm{H}_{0}$ ditolak. Sehingga dapat disimpulkan bahwa terdapat perbedaan yang signifikan antara rerata kemampuan berpikir aljabar siswa yang diajar mengunakan pendekatan pembelajaran konvensional dan siswa yang diajar menggunakan model pembelajaran berbasis masalah (PBM) pada materi aljabar. Dalam hal ini penggunaan model pembelajaran berbasis masalah (PBM) lebih baik dari pada pendekatan pembelajaran konvensional terhadap kemampuan berpikir aljabar siswa khususnya pada materi aljabar.

\section{Pembahasan}

Jenis penelitian ini adalah penelitian eksperimen tentang kemampuan berpikir aljabar siswa dengan menggunakan model pembelajaran berbasis masalah dan pendekatan pembelajaran konvensional pada materi aljabar di kelas $\mathrm{VII}_{2}$ dan $\mathrm{VII}_{3}$ MTs Negeri 2 Kendari. Dalam penelitian ini terdapat kelas eksperimen, yaitu kelas yang diajar menggunakan model pembelajaran berbasis masalah dan kelas kontrol yang diajar menggunakan pendekatan pembelajaran konvensional. Pada kedua kelas diberikan materi pembelajaran masing-masing sebanyak 5 kali pertemuan. Setelah itu diberikan tes kemampuan berpikir aljabar untuk mengetahui model pembelajaran yang lebih baik untuk meningkatkan kemampuan berpikir aljabar siswa.

Salah satu penyebab sulitnya mengembangkan kemampuan berpikir aljabar dalam mata pelajaran matematika adalah guru belum melakukan pendekatan pembelajaran yang tepat untuk meningkatkan kemampuan berpikir aljabar siswa. Guru pada umumnya tidak menggunakan model pembelajaran yang relevan dengan pengalaman siswa dalam dunia nyata yang dapat meningkatkan cara berpikir ke arah salah satu aspek matematika, yaitu aljabar dalam pemecahan masalah. Oleh karena itu, guru perlu menyusun suatu model pembelajaran yang dapat memperbaiki pembelajaran matematika tersebut, yaitu model pembelajaran berbasis masalah (PBM).

Pembelajaran berbasis masalah merupakan suatu model pembelajaran yang diawali dengan penyajian masalah yang relevan dengan pengalaman siswa dalam dunia nyata dan dikaitkan dengan ide-ide atau topik-topik dalam matematika sehingga siswa dapat memahami konsep dengan baik, dapat meningkatkan kemampuan berpikir aljabar, memiliki kemandirian belajar, keterampilan berpartisipasi dalam kerja kelompok, dan kemampuan pemecahan masalah.

Selain itu, model pembelajaran berbasis masalah memotivasi siswa agar dapat menemukan solusi dari suatu permasalahan tanpa bantuan guru sehingga siswa terlibat aktif dalam pembelajaran, juga saling mendukung dan membantu satu sama lain dalam menguasai materi yang diajarkan oleh guru. Penelitian ini bertujuan untuk melihat model pembelajaran mana yang lebih baik dalam meningkatkan kemampuan berpikir aljabar siswa.

Berdasarkan uraian analisis data hasil penelitian dan pengujian hipotesis, berikut ini dikemukakan pembahasan terhadap beberapa temuan sehubungan dengan peningkatan kemampuan berpikir aljabar siswa, berdasarkan model pembelajaran yang digunakan.

Model pembelajaran yang digunakan guru berpengaruh terhadap aktivitas siswa dikelas selama mengikuti proses pembelajaran. Pelaksanaan penelitian ini menggunakan dua jenis pembelajaran. Kelas eksperimen mengunakan pembelajaran berbasis masalah (PBM), sedangkan kelas kontrol menggunakan pendekatan pembelajaran konvensional.

Pendekatan pembelajaran konvensional merupakan pendekatan pembelajaran dimana guru menjadi pusat kegiatan dalam proses pembelajaran, sumber pengetahuan dan kurang melibatkan siswa secara aktif dalam kegiatan belajar. Akibatnya siswa kurang antusias dalam proses pembelajaran dan kurang tertarik memperhatikan materi yang dipelajari serta tidak memahami materi matematika secara mendalam sehingga cepat lupa. Siswa merasa bahwa belajar adalah mengikuti petunjuk guru, yang penting semua yang disampaikan guru dikuasai. Akibatnya siswa tidak mampu menyelesaikan masalah-masalah yang lebih menantang dan sulit yang membutuhkan proses berpikir tingkat tinggi seperti kemampuan berpikir aljabar dan kemampuan berpikir tingkat tinggi lainnya.

Pembelajaran berbasis masalah adalah suatu pembelajaran yang proses pelaksanaannya diawali oleh penyajian masalah kontekstual bagi siswa untuk belajar. Pembelajaran berbasis 
masalah memiliki lima tahapan pembelajaran yaitu: orientasi siswa pada masalah, mengorganisasi siswa untuk belajar, membimbing kelompok atau individu, menyajikan hasil karya, dan menganalisis dan mengevaluasi pemecahan masalah. Rangkaian tahap-tahap dalam pembelajaran ini sangat menekankan kepada siswa agar mampu menyelesaikan suatu masalah dengan idenya sendiri, sehingga materi pelajaran dapat mudah diingat oleh siswa dan tidak mudah dilupakan serta dapat melatih dan meningkatkan kemampuan berpikir aljabar siswa dalam memecahkan masalah matematika.

Proses pembelajaran ini pertama-tama dilakukan kegiatan pendahuluan, yang meliputi pemberian apersepsi, penyampaian tujuan pembelajaran dan pemberian motivasi, kemudian guru menyiapkan bahan ajar dan LKS. Pada kegiatan inti guru memulai dengan memberikan contoh masalah kontekstual yang berkaitan materi yang akan dipelajari.

Selanjutnya guru menyampaikan pokokpokok materi yang akan dipelajari dan kemudian dilakukan pembagian kelompok secara heterogen. Dalam proses pembelajaran ini, siswa dibagi menjadi 6 kelompok dengan tiap kelompok beranggotakan 5 atau 6 orang siswa. Kemudian pada setiap kelompok diberikan bahan ajar dan LKS untuk dikerjakan secara berkelompok. Pada tahap ini, guru berperan memberi pengarahan dan bimbingan kepada siswa melalui penjelasan atau pertanyaan yang mengarah pada penyelesaian masalah bila diminta langsung oleh siswa dengan memanfaatkan media pembelajaran.

Pada awal pelaksanaan perlakuan, kelas eksperimen mengalami sedikit hambatan. Guru dan siswa membutuhkan waktu untuk menyesuaikan diri dengan pendekatan pembelajaran yang baru diterapkan di kelas, terutama pada saat pembentukan kelompok dan pemecahan masalah, sehingga proses ini cukup menyita waktu pembelajaran. Guru juga masih mengalami kesulitan dalam memotovasi siswa untuk mengajukan masalah, mengumpulkan informasi-informasi untuk mendapatkan pemecahan masalah, dikarenakan guru juga masih menyesuaikan diri dengan pendekatan pembelajaran berbasis masalah, akibatnya siswa belum dapat menyimpulkan atau merangkum materi yang telah dipelajari secara maksimal.

Selain itu, siswa masih mengalami kesulitan dalam menggali dan mengolah informasi dari LKS dan bahan ajar yang diberikan. Pada pertemuan pertama ini, guru kurang memberikan contoh masalah kontekstual yang berkaitan materi yang akan dipelajari. Akan tetapi, pada pertemuan pertemuan pertama ini siswa penuh perhatian dalam belajar kelompok dan melakukan kerjasama yang aktif bersama teman-teman kelompoknya meskipun hanya sedikit siswa yang berani mengemukakan pendapat atau memberikan tanggapan ketika guru memberikan pertanyaan.

Pada pertemuan kedua dan pertemuanpertemuan selanjutnya, proses pembelajaran dapat berjalan dengan baik dan lancar. Meskipun pada pertemuan kedua dan ketiga beberapa siswa masih mengalami kesulitan dalam menggali dan mengolah informasi dari LKS dan sumber belajar lainnya, sehingga siswa tersebut belum mampu menyelesaikan soal sendiri disebabkan tidak dapat menemukan konsep penyelesaian dari masalah yang diberikan (LKS).

Namun dengan arahan dan bimbingan dari guru, siswa sudah mulai mengerti dengan model pembelajaran berbasis masalah. Guru dan siswa sudah menunjukkan sikap yang antusias dalam proses pembelajaran. Selain itu, guru sudah dapat memberi umpan balik terhadap respon-respon siswa dan mendorong siswa mengumpulkan informasi untuk mendapatkan solusi dari masalah yang diberikan. Sehingga dapat disimpulkan bahwa, siswa juga memerlukan waktu untuk beradaptasi terhadap suatu pembelajaran yang baru diterapkan. Ini juga terlihat dari persentase ketercapaian aspek yang diamati, secara keseluruhan mengalami peningkatan jika dibandingkan dengan persentase pada pertemuan pertama.

Data kemampuan berpikir aljabar siswa diperoleh melalui tes kemampuan berpikir aljabar. Tes tersebut diberikan kepada siswa kelas eksperimen dan kelas kontrol setelah perlakuan (post-test). Untuk membandingkan kemampuan berpikir aljabar antara kelas kontrol dan kelas eksperimen, digunakan analisis deskriptif dan analisis inferensial. Analisis deskriptif digunakan untuk membandingkan ukuran data statistika, yaitu: data terbesar $\left(X_{\max }\right)$, data terkecil $\left(X_{\min }\right)$, rata-rata $(\bar{x})$, median $(M e)$, modus $(M o)$, varians, dan standar deviasi $(s d)$ pada kedua kelas. Sedangkan analisis inferensil digunakan untuk menguji hipotesis perbedaan kemampuan berpikir aljabar 
siswa untuk menguji hipotesis dengan statistik uji-t.

Jika dilihat dari analisis deskriptif kemampuan berpikir aljabar dari kedua kelas dapat dilihat bahwa rata-rata dan median kemampuan berpikir aljabar siswa yang diajar dengan model pembelajaran berbasis masalah lebih tinggi dari pada siswa yang diajar dengan pendekatan konvensional. Demikian pula nilai maksimun dan minimum siswa yang diajar dengan model pembelajaran berbasis masalah lebih tinggi dari pada siswa yang diajar dengan pendekatan konvensional. Dengan demikian, dapat dikatakan bahwa secara deskriptif kemampuan berpikir aljabar siswa yang diajar dengan model pembelajaran berbasis masalah lebih baik dari pada siswa yang diajar dengan pendekatan pembelajaran konvensional.

Hal tersebut sejalan dengan temuan penelitian yang dilakukan oleh Fachrurazi (2011: 85-86) yang mengungkapkan bahwa dengan penggunaan pemecahan masalah sebagai konteks dalam matematika, maka fokus kegiatan belajar sepenuhnya berada pada siswa. Kegiatan belajar yang dimaksud yaitu berpikir menemukan solusi dari suatu masalah matematika termasuk proses untuk memahami suatu konsep dan prosedur matematika yang terkandung dalam masalah tersebut. Melalui aktivitas seperti ini, kemampuan kognitif siswa mendapat kesempatan untuk diberdayakan dan dimantapkan. Jadi, pembelajaran dengan model pembelajaran berbasis masalah dibandingkan dengan pendekatan pembelajaran konvensional, menunjukkan pengaruh yang lebih baik terhadap kemampuan berpikir aljabar siswa.

Berdasarkan hasil analisis data dengan menggunakan uji- $t$, dapat dilihat bahwa terdapat perbedaan yang signifikan antara rerata kemapuan berpikir aljabar siswa yang diajar mengunakan model pembelajaran berbasis masalah dan siswa yang diajar menggunakan pendekatan pembelajaran konvensional pada materi aljabar. Dalam hal ini kemampuan berpikir lajabar siswa yang diajar dengan menggunakan model pembelajaran berbasis masalah lebih tinggi dari pada kemampuan berpikir aljabar siswa yang diajar dengan pendekatan pembelajaran konvensional. Implikasi dari hasil penelitian ini adalah bahwa model pembelajaran berbasis masalah memberikan pengaruh yang lebih baik terhadap kemampuan berpikir aljabar siswa dibandingkan pendekatan pembelajaran konvensional pada materi aljabar.

\section{Simpulan dan Saran Simpulan}

Berdasarkan hasil penelitian, dapat disimpulkan sebagai berikut:

1. Kemampuan berpikir aljabar siswa yang diajarkan dengan menggunakan model pembelajaran berbasis masalah (PBM) diperoleh rata-rata sebesar 67.5, median sebesar 67.5, modus sebesar 70, standard deviasi sebesar 12.247, dan variance sebesar 150.

2. Kemampuan berpikir aljabar siswa yang diajarkan dengan menggunakan pendekatan pembelajaran konvensional diperoleh ratarata sebesar 57.188, median sebesar 55, modus sebesar 65 , standard deviasi sebesar 9.153, dan variance sebesar 83.77.

3. Rerata kemampuan berpikir aljabar siswa setelah diajar dengan menggunakan model pembelajaran berbasis masalah (PBM) lebih baik secara signifikan daripada rerata kemampuan berpikir aljabar siswa setelah diajar dengan menggunakan pendekatan pembelajaran konvensional.

\section{Saran}

Berdasarkan simpulan di atas, saran yang dapat diberikan sebagai berikut:

1. Kepada para guru yang mengajar mata pelajaran Matematika sekiranya dapat menggunakan model pembelajaran berbasis masalah (PBM) sebagai salah satu alternatif model pembelajaran dalam pembelajaran matematika untuk mengoptimalkan kemampuan berpikir aljabar siswa.

2. Bagi siswa hendaknya selalu berusaha memahami setiap materi ajar matematika khususnya aljabar dengan tuntas dan berusaha mengingat materi yang telah dipelajari, mampu melihat kaitannya dengan materi lain karena hal ini akan mempengaruhi kemampuan berpikir aljabar siswa. 


\section{Daftar Pustaka}

Fachrurazi. (2011). Penerapan Pembelajaran Berbasis Masalah untuk Meningkatkan Kemampuan Berpikir Kritis dan Komunikasi Matematis Siswa Sekolah Dasar. Edisi Khusus No. 1 Hal. 76-89.

Hayati, Laila. (2013). Pembelajaran Pendidikan Matematika Realistik untuk mengembangkan kemampuan berpikir Aljabar Siswa, Makalah dipresentasikan dalam seminar Nasional Matematika dan pendidikan Matematika denagn tema Penguatan Peran Matematika dan Pendidikan Matematika untuk Indonesia Lebih Baik, Yogyakarta: FMIPA UNY.

Lew, Hee-Chan. (2004). "Developing Algebraic Thinking in Early Grades: Case Study of Korean Elementary School Mathematic." In The Mathematics Educator, Vol. 8, No. 1.

Patton, Barba and Estella De Los Santos. (2012). Analyzing Algebraic Thinking Using Gues My Number Problem, International Journal of Intruction, Volume 5 Hal. 7.

Rusman. (2010). Model-model Pembelajaran Mengembangkan Profesionalisme Guru. Jakarta: Rajawali Press.

Sari, Shinta; Sri Elniati; dan Ahmad Fauzan. (2014). Pengaruh Pendekatan Pembelajaran Berbasis Masalah
Terhadap Kemampuan Pemecahan Masalah Matematika Siswa Kelas VIII SMP Negeri 1 Padang Tahun Pelajaran 2013/2014. Jurnal Pendidikan Matematika, Part 1. Vol. 3 No. 2 Hal. 54-59.

Siswono, Tatag Yuli Eko. (2007). Penjenjangan Kemampuan Berpikir Kreatif dan Identifikasi Tahap Berpikir Kreatif Siswa dalam Memecahkan dan Mengajukan Masalah Matematika. Universitas Terbuka. Purwokerto.

Sudarman. (2007). Problem Based Learning: Suatu Model Pembelajaran untuk Mengem-bangkan dan Meningkatkan Kemampuan Memecahkan Masalah. Jurnal Pendidikan Inovatif Vol. 02 No. 02 Hal. 68-73.

Sugiyono. (2013). Metode Penelitian Kuantitatif, Kualitatif, dan $R$ \& D. Bandung: Alfabeta.

Wardhani, Sri. (2004). Permasalahan Kontekstual Mengenalkan Bentuk Aljabar di SMP. Yogyakarta: Pusat Pengembangan Penataran Guru (PPPG) Matematika.

Warsitasari, Wahyu Dwi. (2015). Berpikir Aljabar Dalam Pemecahan Masalah Matematika. Jurnal APOTEMA, Vol. 1, No. 1 Hal. 1-17. 